revealed by weather radar. Q. J. R. Meteorol. Soc., 2010, 136, $222-238$.

16. Vinoj, V., Rasch, P. J., Wang, H., Yoon, Jin-Ho, Landu, K., Singh, B. and Ma, Po-Lun, Short-term modulation of Indian summer monsoon rainfall by West Asian dust. Nature Geosci., 2014, 7, 308-313.

17. Platnick, S. et al., MODIS Atmosphere L3 Daily Product. NASA MODIS Adaptive Processing System, Goddard Space Flight Center, USA, 2015; http://dx.doi.org/10.5067/MODIS/MOD08 D3.006.

18. Huffman, G. J. et al., The TRMM Multisatellite Precipitation Analysis (TMPA): quasi-global, multiyear, combined-sensor precipitation estimates at fine scales. J. Hydrometeorol., 2007, 8, 38 55.

19. Dee, D. P. et al., The ERA-interim reanalysis: configuration and performance of the data assimilation system. Q. J. R. Meteorol. Soc., 2011, 137, 553-597.

20. Saha, S. et al., The NCEP climate forecast system reanalysis. Bull. Am. Meteorol. Soc., 2010, 91, 1015-1057.

21. Rao, Y. P., Meteorological Monograph Synoptic Meteorology, No. 1/1976: South West Monsoon, India Meteorological Department, 1979, pp. 1-379; http://imdpune.gov.in/Weather/Reports/sw\%20 monsoon\%20whole\%20book.pdf

22. Pant, G. and Kumar, K., Climates of South Asia, John Wiley, Hoboken, NJ, USA, 1997

23. Tyrlis, E., Lelieveld, J. and Steil, B., The summer circulation over the eastern Mediterranean and the Middle East: influence of the South Asian monsoon. Climate Dyn., 1997, 40, 1103.

24. Najafi, M. S., Sarraf, B. S. and Zarrin, A., Climatology of atmospheric circulation patterns of Arabian dust in western Iran. Environ. Monit. Assess., 2017, 189, 473.

25. Bollasina, M. and Nigam, S., The summertime 'heat' low over Pakistan/Northwestern India: evolution and origin. Climate Dyn., 2011, 37, 957-970.

26. Krishnan, R., Kumar, V., Sugi, M. and Yoshimura, J., Internal feedbacks from monsoon-midlatitude interactions during droughts in the Indian summer monsoon. J. Atmos. Sci., 2009, 66(3), 553-578.

27. Anoop, T. R. et al., On the generation and propagation of Makran swells in the Arabian Sea. Int. J. Climatol., 2019, 1-9.

ACKNOWLEDGEMENTS. We thank the following data sources: ECMWF ERA Interim, NOAA CFSR, NASA MODIS AOD and TRMM rainfall product. This study was supported by the Ministry of Earth Sciences, Government of India. We thank the Director, National Centre for Earth Science Studies, Thiruvananthapuram for encouragement and support.

Received 17 September 2018; accepted 20 June 2019

\section{Boron measurement in tourmaline from pegmatite veins, Simdega area, Chhotanagpur Gneissic Complex, Eastern India using Electron Probe Microanalysis}

\author{
Deepak Kumar, Dinesh Pandit, Abhinay Sharma \\ and N. V. Chalapathi Rao*
}

Mantle Petrology Laboratory, Department of Geology,

Centre of Advanced Study, Institute of Science,

Banaras Hindu University, Varanasi 221 005, India

Tourmaline group of minerals, the primary source of boron, are cyclosilicates which are widespread in the earth's crust. Earlier studies involving the nomenclature and classification of tourmaline were based on the measurement of its common elements (Al, Mn, Fe, $\mathrm{Mg}$, etc.). In all such studies, boron was assumed to be fixed in the composition and restricted only to the triangular structural site. However, recent discovery of the presence of boron in the tetrahedral structural site as well, necessitates the measurement of boron content. Much of the earlier attempts to measure boron were based on solution methods, and electron microprobe analysis (EPMA) was the least used due to low levels of detection of its analytical crystals. In the present study, we quantify boron - particularly along with fluorine and other major elements - in tourmaline grains using high-sensitivity PC3 analytical crystal. We found that the measured boron content slightly exceeds that of the stoichiometrically calculated boron. Also, the studied tourmalines come under the alkali group in general and belong to the schorldravite solid solution series in particular.

Keywords: Boron, electron probe micro analysis, pegmatite, tourmaline.

TOURMALINE group of minerals are cyclosilicates with significant amount of boron and are widespread in the earth's crust. Tourmaline is regarded as a good indicator for understanding the crustal evolution because its paragenesis extends to a wide range of physico-chemical fields and can constitute a petrological indicator ${ }^{1-3}$. Being a chemically and mechanically resistant mineral, its occurrence in clastic sedimentary rocks is common ${ }^{4,5}$. Tourmaline can also form during the late stage of diagenesis $^{6-9}$. It can be related to two completely miscible solid solution series: schorl-dravite and schorl-elbaite. Some common end-members in the tourmaline group include schorl, dravite, elbaite, tsiliasite, uvite, liddicoatite, alkali-defect tourmaline, proton-deficient tourmaline, buergerite and ferridravite ${ }^{10}$.

*For correspondence. (e-mail: nvcrao@bhu.ac.in) 


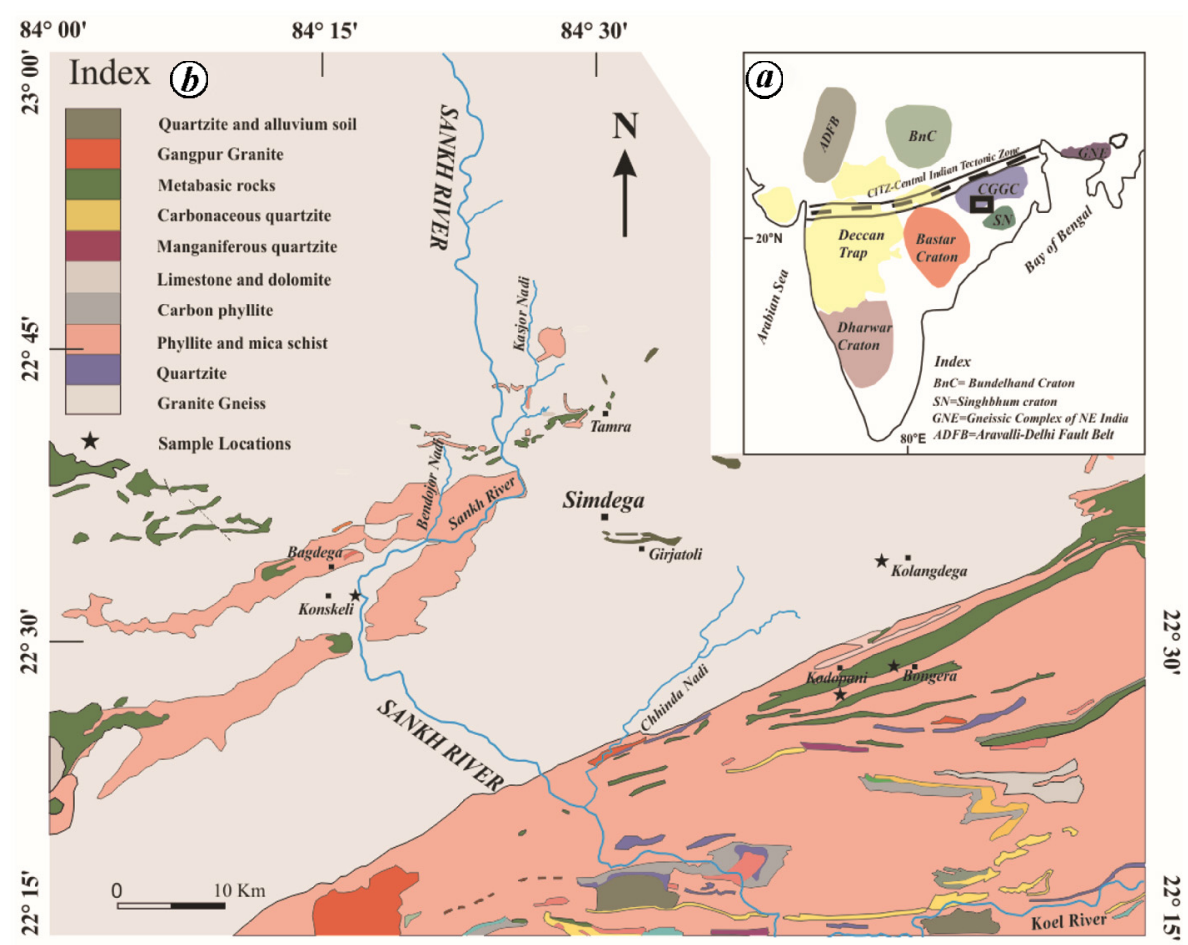

Figure 1. $\boldsymbol{a}$, Outline map of India showing different cratons of the Indian Shield ${ }^{46}$. $\boldsymbol{b}$, Geological map of the study area located in the Chhotanagpur Gneissic Complex (CGC), eastern India ${ }^{47}$.

Tourmaline can be defined with the generalized formula $X Y_{3} Z_{6}\left(\mathrm{~T}_{6} \mathrm{O}_{18}\right)\left(\mathrm{BO}_{3}\right)_{3} \mathrm{~V}_{3} \mathrm{~W}$ (ref. 11). It has two different types of octahedral sites: $Z$ site and the slightly larger $Y$ site ${ }^{12,13}$. The $Z$ site is filled by $\mathrm{Al}$, but $\mathrm{Fe}^{2+}, \mathrm{Fe}^{3+}, \mathrm{Ti}, \mathrm{Mg}$, $\mathrm{Cr}$ and $\mathrm{V}^{3+}$ can also replace $\mathrm{it}^{14-20}$. The relatively larger $Y$ site allows extensive elemental substitutions involving monovalent, divalent, trivalent and quadrivalent cations such as $\mathrm{Li}, \mathrm{Mg}, \mathrm{Fe}^{2+}, \mathrm{Mn}^{2+}, \mathrm{Zn}, \mathrm{Al}, \mathrm{Cr}^{3+}, \mathrm{V}^{3+}, \mathrm{Fe}^{3+}, \mathrm{Ti}^{4+}$ (refs 17, 21-23). The $X$ site accommodates $\mathrm{Na}, \mathrm{Ca}, \mathrm{Mg}$ and vacancies ${ }^{24}$. Boron $(=3)$ has no apparent substitution in the triangular site ${ }^{25,26}$. However, excess boron $(>3)$ can substitute for $\mathrm{Si}$ in the tetrahedral $(\mathrm{T}) \mathrm{site}^{27-31} \cdot \mathrm{F}^{-}$or $\mathrm{O}^{2-}$ can substitute for $\mathrm{OH}^{-}$in the hydroxyl sites $\mathrm{V}$ and $\mathrm{W}^{24,32}$.

Knowledge about the concentration of low atomic number elements (boron, oxygen and fluorine) in tourmaline is significant in understanding the crystallization history. Quantification of low atomic number elements, especially that of boron, was previously attempted using different methods. For example, Iyengar ${ }^{33}$ measured boron in fibrous tourmaline by the wet chemical method; $\mathrm{Babu}^{34}$ estimated boron in achroite variety of tourmaline by the gravimetry method. Bastin and Heijligers ${ }^{35}$ analysed boron in chemical compounds $\left(\mathrm{TiB}_{2}, \mathrm{ZrB}_{2}\right)$ using electron microprobe analysis (EMPA). Ertl et al. ${ }^{36}$ showed using secondary ion mass spectrometer (SIMS) that (i) B and Al substitute for $\mathrm{Si}$ at the tetrahedral $\mathrm{T}$ site, and (ii) $\mathrm{B}$ and $\mathrm{Al}$ show inverse relation from core to rim at the $\mathrm{T}$ site in tourmaline of the Himalaya mine, Mesa Grande, California, USA. On the other hand, tetrahedral boron ( $>3$ ) concentration at the $\mathrm{T}$ site by combining chemical, crystallographic and spectroscopic data with NMR study has also been reported ${ }^{27-31}$. Henry et al. ${ }^{37}$ came up with an assumption, based on total concentration of boron in various tourmaline series, that this element fully occupies the triangular B site and can be calculated using stoichiometric constraints (i.e. $\mathrm{B}=3$ ). Thus, despite the fact that chemical analysis of boron was attempted, earlier studies involving EPMA have been limited on geological samples; they also lacked analytical accuracy and precision, and hence were not satisfactory.

In recent years, advancement in technology through the development of new EPMA models involving highsensitivity crystals has further increased scientific interest in the characterization of minerals containing elements with low atomic number $(<9)$, such as beryllium, boron, carbon, nitrogen, oxygen and fluorine, which motivated us to initiate the present study. Here we quantify boron together along with fluorine and other major elements in tourmaline grains using SXFive EPMA made by CAMECA, France.

The east-west trending Chhotanagpur Gneissic Complex (CGC) is a sub-arcuate belt of the east Indian Shield ${ }^{38-40}$ (Figure $1 a$ ). The study area in CGC is marked by two dominant lithologies, namely: (i) granite-gneiss, and (ii) phyllite and mica schist. The granite-gneiss has enclaves of older ENE-WSW trending supracrustals which contain metabasics, metapelites and metapsammites $^{41}$. Several basic to metabasic dykes cross-cut the 

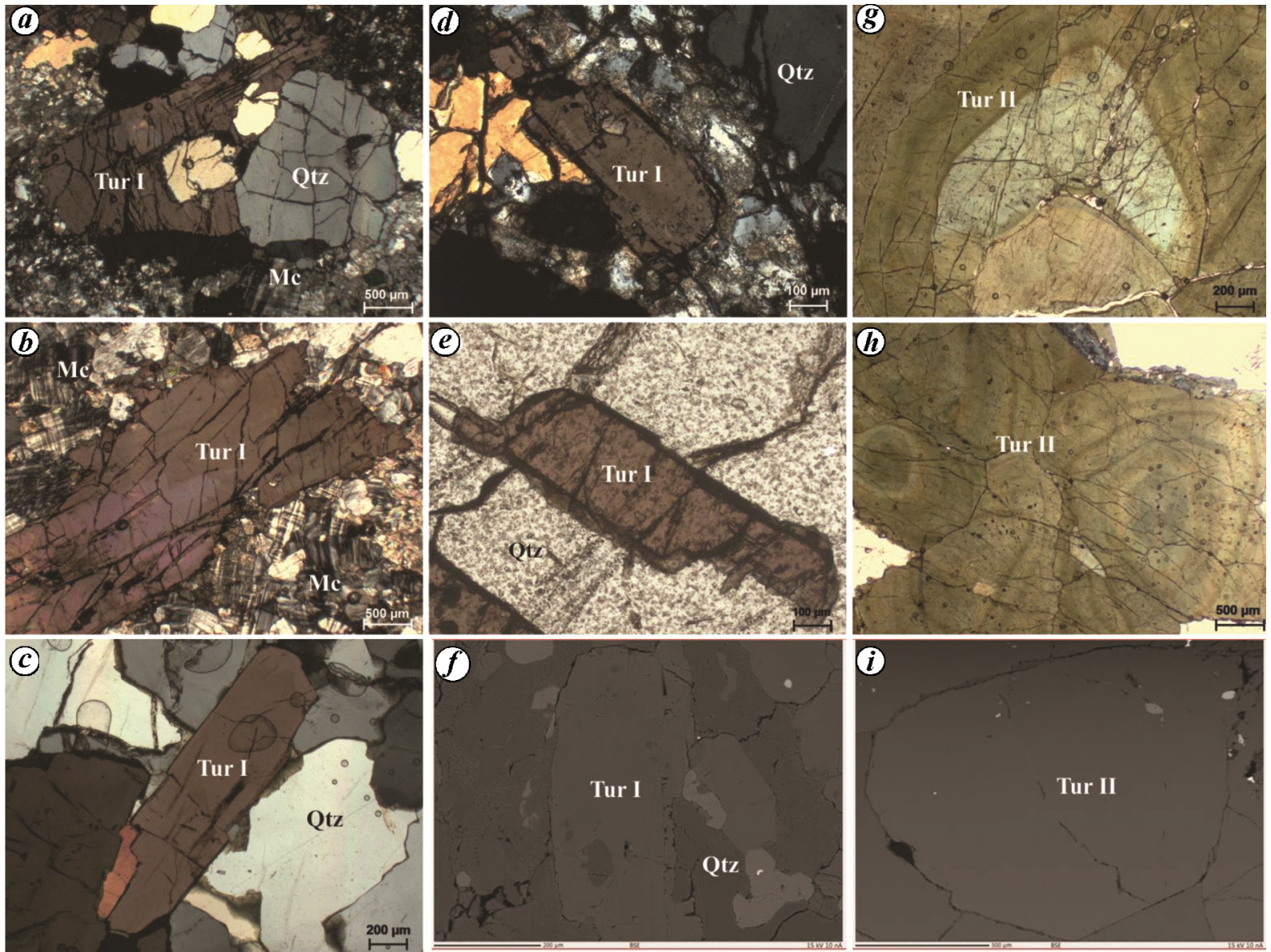

Figure 2. Photomicrographs of tourmaline occurring in Simdega pegmatites. $\boldsymbol{a}-\boldsymbol{f}$, Tur I showing no optical zoning. $\boldsymbol{g}-\boldsymbol{i}$, Tur II showing optical zoning. $\boldsymbol{f}$ and $\boldsymbol{i}$ are backscattered electron images. Mc, Microcline, Tur, Tourmaline; Qtz, Quartz.
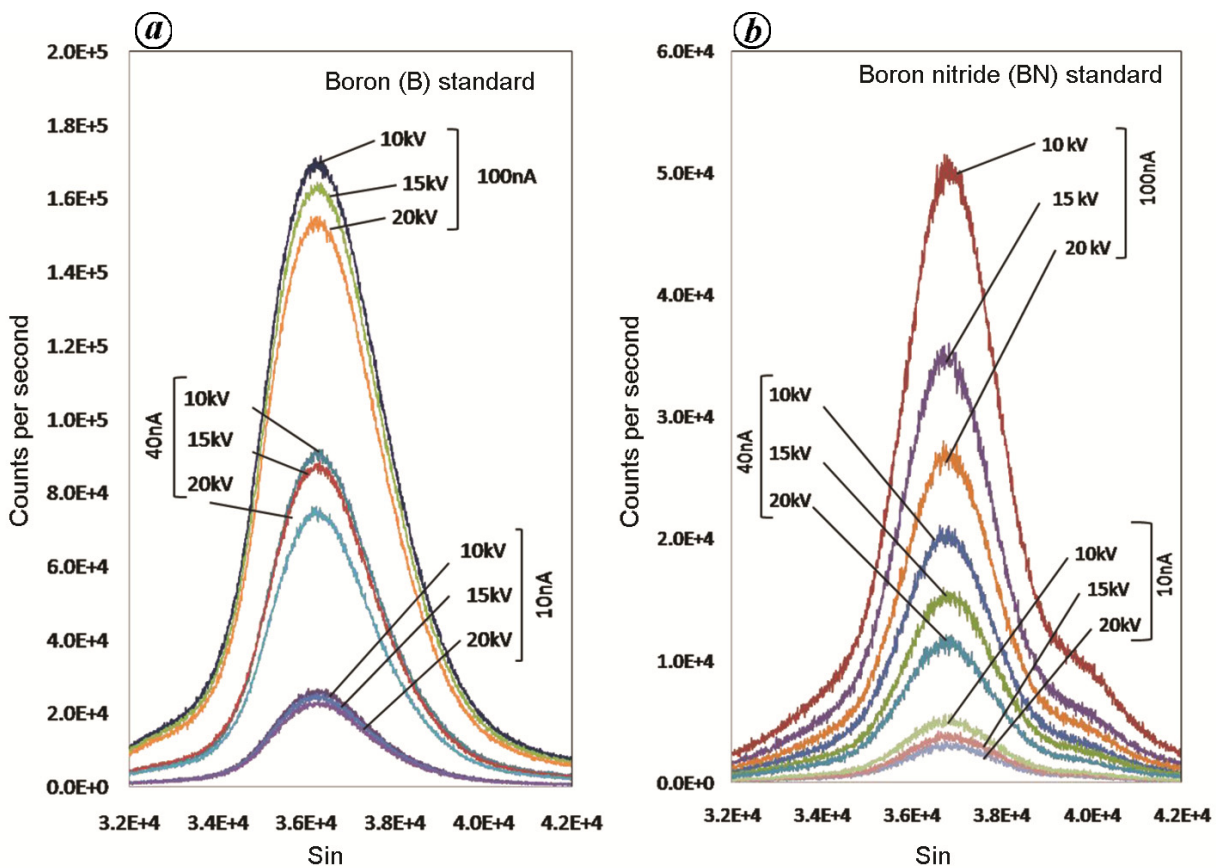

Figure 3. Wavelength dispersive spectra of boron produced at different voltage and current values using PC3 crystal at two different standards (boron metal standard and boron nitride (BN) standard). 

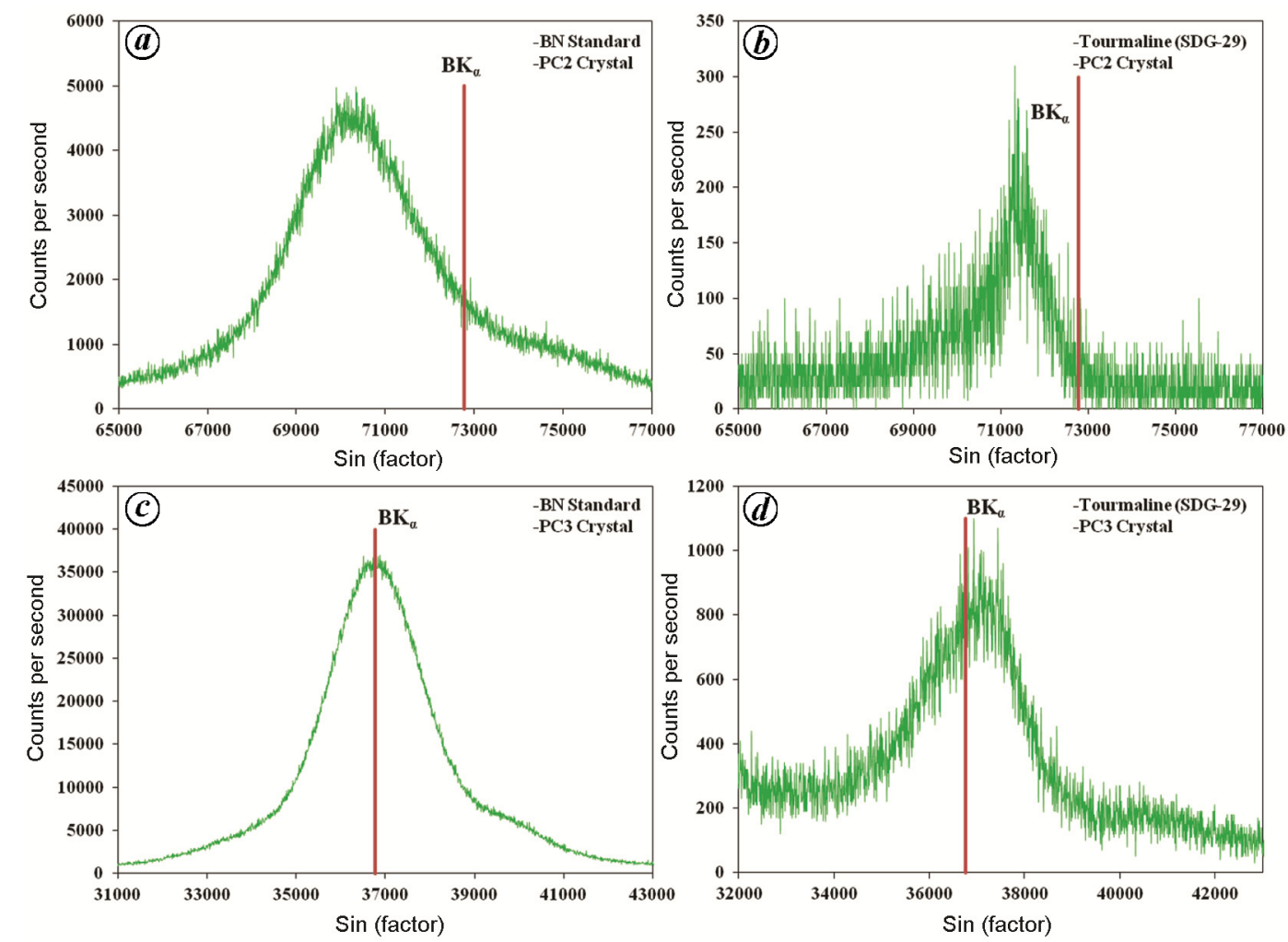

Figure 4. WDS spectra of boron generated at $15 \mathrm{kV}$ and $100 \mathrm{nA}$ at: (a) BN standard using PC2 crystal; (b) tourmaline sample using PC2 crystal; (c) BN standard using PC3 crystal and (d) tourmaline sample using PC3 crystal.

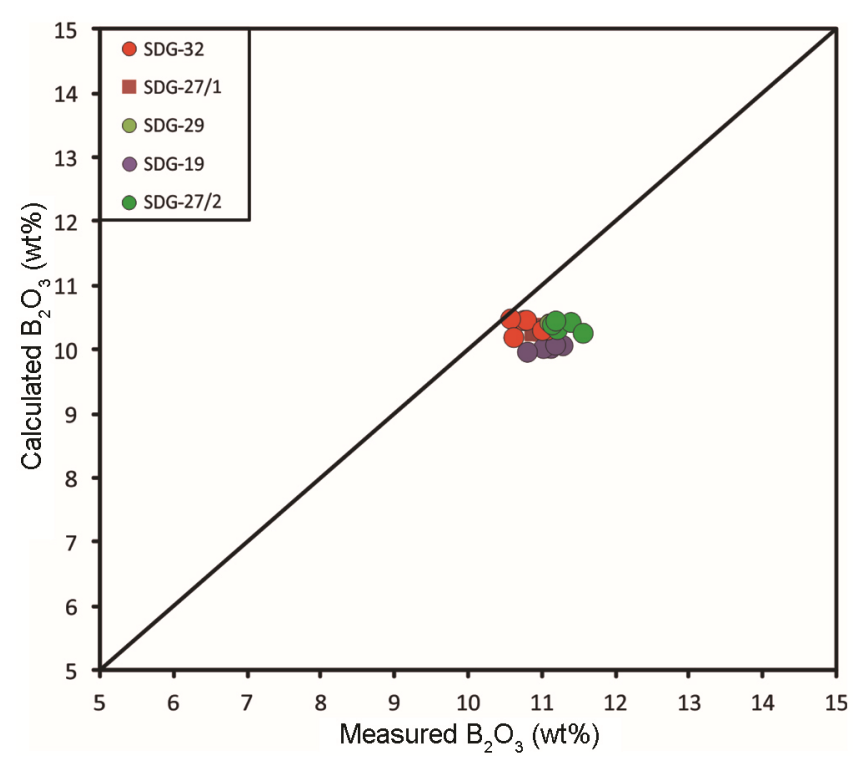

Figure 5. Binary plot between measured boron and calculated boron.

country rock (Figure $1 b$ ). Phyllite and mica schist dominantly occur in the southern part having veins and patches of quartzite and limestone of varied composition. Tourmaline development is common in the form of quartz-tourmaline pegmatitic veins at the contact region of granite-gneiss and metapelites. Two types of tourma- line in the pegmatitic veins have been observed from the Simdega area, i.e. Tur I: euhedral prismatic brown schorl tourmaline with no apparent optical zoning collected from the Konskeli, Kolangdega and Kodopani villages, and Tur II - oval to prismatic, green dravite tourmaline cluster showing optical zoning collected from the Bongera (Figure 2).

The electron probe microanalyser has five spectrometers (SP1-LiF, SP2-PC3, SP3-LPET, SP4-LTAP and SP5PC0) and a combination of different crystals installed in these spectrometers. Thin sections were coated with $20 \mathrm{~nm}$ thin layer of carbon (LEICA-EM ACE200 carbon coater). Analytical conditions were tested on the two standards, viz. boron (B) metal standard and boron nitride (BN) standard both of which were provided by CAMECA, France (Figure 3). A focused beam of diameter $\sim 1 \mu \mathrm{m}$ was used on the homogeneous volume of the sample throughout the analysis. During the experiment heterogeneity, other than composition difference affecting X-ray counts, is least since we carefully polished the samples. Repeated analysis was done and more than 500 points were analysed during the experiment at an accelerating voltage of $15 \mathrm{kV}$ and current of $40 \mathrm{nA}$. A special type of crystal (PC3) was used for the measurement of light elements like $\mathrm{Be}, \mathrm{B}$ and $\mathrm{C}$, which also prevents overlapping of the counts produced by other similar types of elements. The instrument was operated with SXFive 

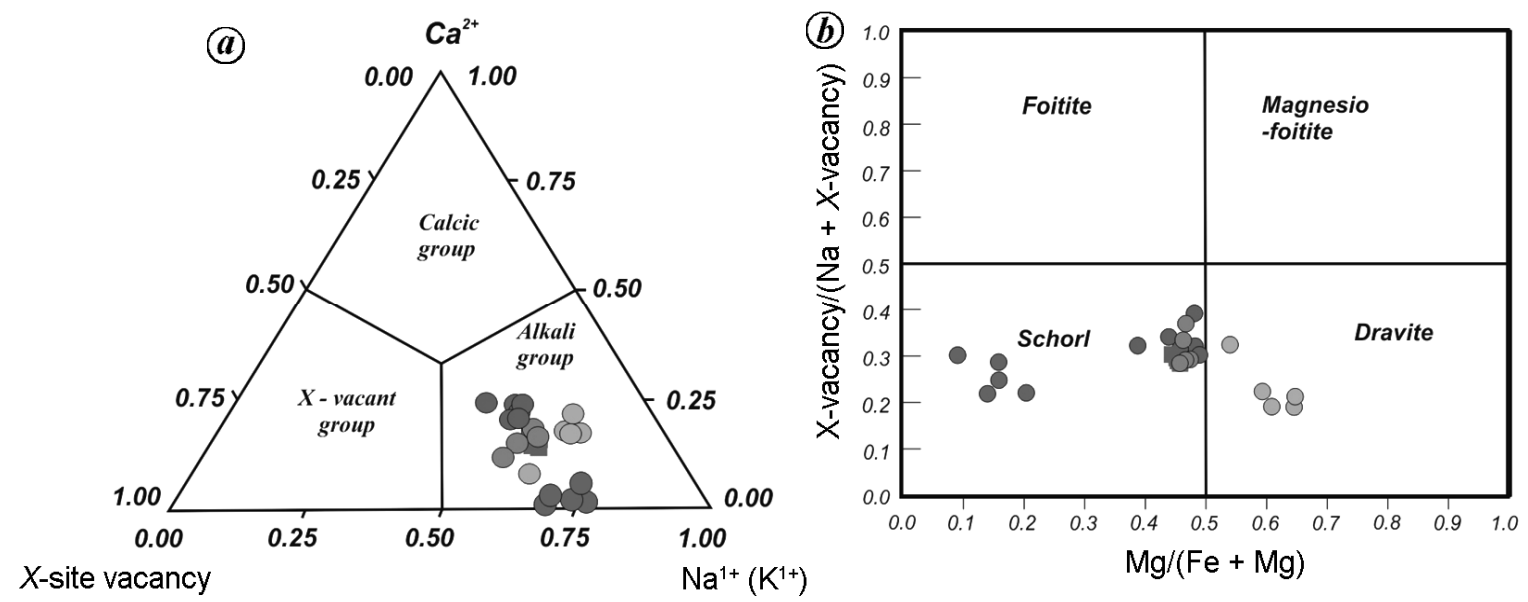

Figure $6 \boldsymbol{a}, \boldsymbol{b}$. Tourmaline classification plot of the selected samples ${ }^{10}$ (legend is the same as in Figure 5).

Table 1. Electron probe microanalyser calibration settings for tourmaline quantification. The X-ray spectral lines used along with details of natural and synthetic standards are listed

\begin{tabular}{|c|c|c|c|c|c|c|c|c|}
\hline $\begin{array}{l}\text { Atomic } \\
\text { number }\end{array}$ & $\begin{array}{l}\text { Element } \\
\text { X-ray }\end{array}$ & Crystal & $\begin{array}{l}\text { Peak time } \\
\quad(\mathrm{ns})\end{array}$ & $\begin{array}{c}\text { Background } \\
(- \text { ve })\end{array}$ & $\begin{array}{c}\text { Background } \\
(+ \text { ve })\end{array}$ & Standard & Composition & $\begin{array}{l}\text { Standard intensity } \\
(\mathrm{cps} / \mathrm{nA})\end{array}$ \\
\hline 5 & $\mathrm{~B}-\mathrm{K}_{\alpha}$ & $\mathrm{PC} 2$ & 30 & -4500 & +1000 & Boron nitride & $\mathrm{BN}$ & 49.92 \\
\hline 5 & $\mathrm{~B}-\mathrm{K}_{\alpha}$ & $\mathrm{PC} 3$ & 120 & -4000 & +2500 & Boron nitride & $\mathrm{BN}$ & 369.978 \\
\hline 9 & $\mathrm{~F}-\mathrm{K}_{\alpha}$ & LTAP & 10 & -500 & +500 & Fluorite & $\mathrm{CaF}_{2}$ & 49.529 \\
\hline 11 & $\mathrm{Na}-\mathrm{K}_{\alpha}$ & TAP & 10 & -500 & +500 & Albite & $\mathrm{NaAlSi}_{3} \mathrm{O}_{8}$ & 387.505 \\
\hline 14 & $\mathrm{Si}-\mathrm{K}_{\alpha}$ & TAP & 10 & -500 & +500 & Wollostonite & $\mathrm{CaSiO}_{3}$ & 464.060 \\
\hline 17 & $\mathrm{Cl}-\mathrm{K}_{\alpha}$ & PET & 10 & -500 & +500 & Sodium chloride & e $\mathrm{NaCl}$ & 176.506 \\
\hline 19 & $\mathrm{~K}-\mathrm{K}_{\alpha}$ & PET & 10 & -500 & +500 & Orthoclase & $\mathrm{KAlSi}_{3} \mathrm{O}_{8}$ & 69.222 \\
\hline 20 & $\mathrm{Ca}-\mathrm{K}_{\alpha}$ & PET & 10 & -500 & +500 & Diopside & $\mathrm{CaMgSi}_{2} \mathrm{O}_{6}$ & 354.887 \\
\hline 22 & $\mathrm{Ti}-\mathrm{K}_{\alpha}$ & LIF & 10 & -500 & +500 & Rutile & $\mathrm{TiO}_{2}$ & 58.679 \\
\hline
\end{tabular}

software using $\mathrm{LaB}_{6}$ as the filament in the gun source. Andradite, a natural silicate mineral, was used to verify positions of crystals in all five spectrometers.

The PC2 and PC3 crystals have been installed in the SP2 spectrometer. In the PC3 crystal, only three elements, i.e. beryllium, boron and carbon can be accommodated at very far positions. Hence a wide range of background offset can be selected with least interference. Peak shift and peak alteration is a common phenomenon in the quantification of low atomic number elements, and can be reduced by the selection of a crystal that contains the least number of elements. The resulting large background offset value can be used in the measurement, and the PC3 crystal fulfils this requirement. In the wavelength dispersive spectra (WDS), spectra of boron generated by the PC2 crystal (Figure $4 a$ and $b$ ), on the $\mathrm{BN}$ standard and a tourmaline sample peak shift is relatively large compared to that of PC3 crystal (Figure $4 c$ and $d$ ). Hence we infer that the PC3 crystal is more suitable for the quantification of boron with higher satisfaction.
Table 1 presents the analytical conditions for boron in spectrometer SP2 along with those for major oxides. The $\mathrm{X}$-ray intensity displays an inverse relation with voltage at the same current for boron, which is due to the migration of volatile elements (Figure 3). The X-ray intensity is best tested at low voltage and current, but we have used $15 \mathrm{kV}$ and $40 \mathrm{nA}$ since excitation of X-rays of other elements present ( $\mathrm{Fe}, \mathrm{Mg}, \mathrm{Al}$, etc.) is reduced at such a low voltage and current.

The calibration of $\mathrm{B}-\mathrm{K}_{\alpha}$ was carried out at $15 \mathrm{kV}$ and $40 \mathrm{nA}$ using $\mathrm{BN}$ standard with the background offset ranging from -4500 to +1000 on the PC2 crystal and from -4000 to +2500 on the PC3 crystal attached to the SP2 spectrometer. The time for analysis was set to $30 \mathrm{sec}$ each for the peak and the background. The WDS spectra was generated at $15 \mathrm{kV}$ and $100 \mathrm{nA}$. The observed standard intensity of $\mathrm{B}-\mathrm{K}_{\alpha}$ on $\mathrm{PC} 2$ crystal at $\mathrm{BN}$ standard was $49.92 \mathrm{cps} / \mathrm{nA}$, whereas on the PC3 crystal it was $369.97 \mathrm{cps} / \mathrm{nA}$ for the same analytical conditions. Since the standard intensity of PC3 is approximately 7-8 times 


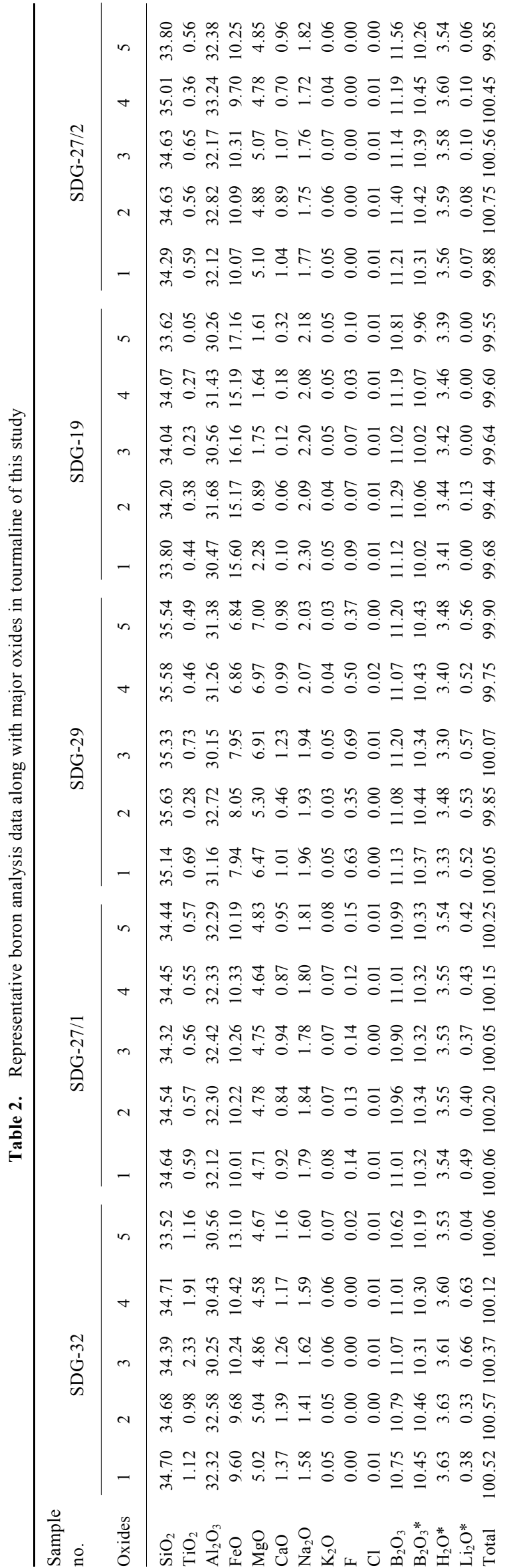

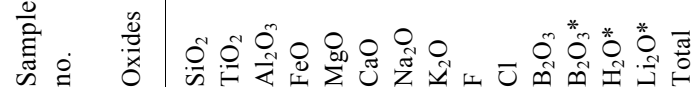

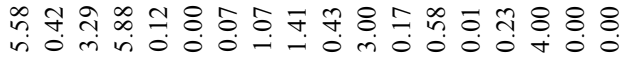

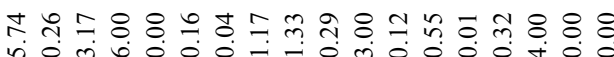

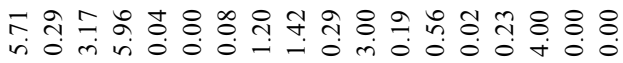

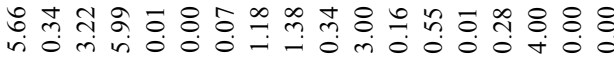

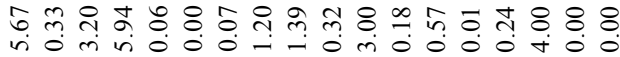

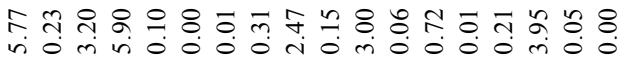

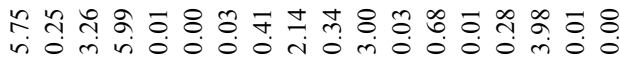

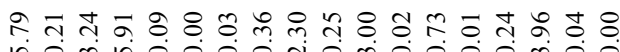

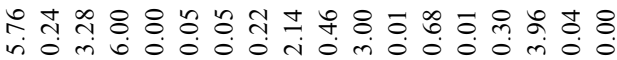

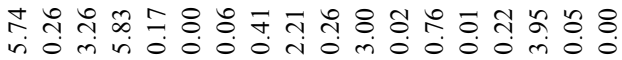

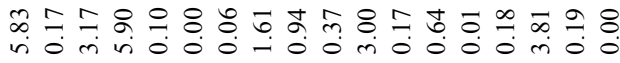

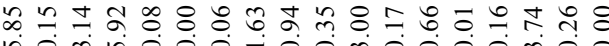

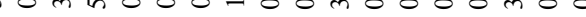

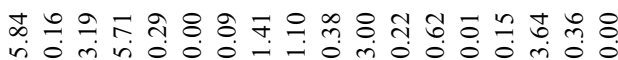

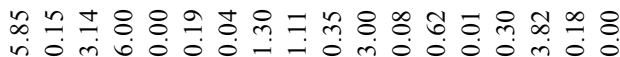

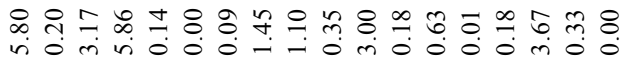

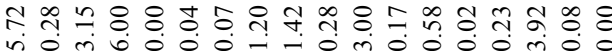

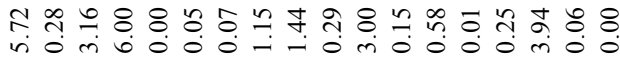

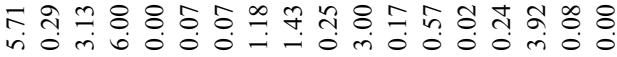

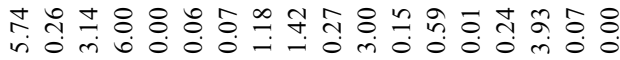

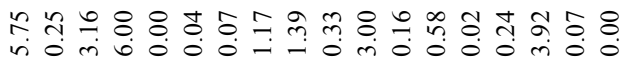
正

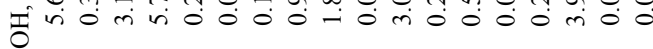

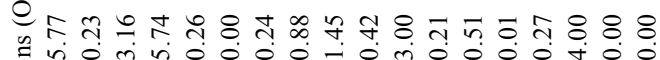

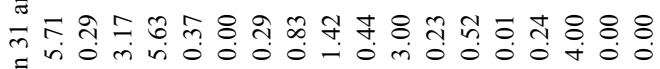

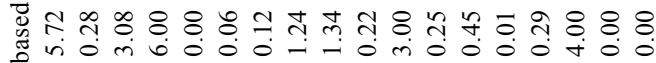

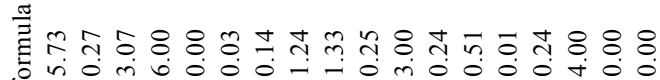

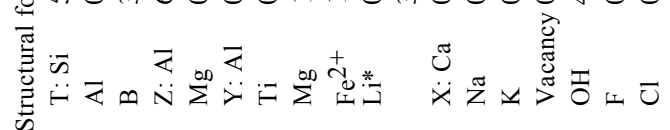


higher than that of the PC2 for same analytical conditions, the former is more useful for measurement of boron concentration.

In the present study, five samples of tourmaline collected from different pegmatitic veins of CGC were analysed. The composition of tourmaline in terms of the major element oxides, viz. $\mathrm{SiO}_{2} \quad(33.52-35.63 \mathrm{wt} \%)$, $\mathrm{Al}_{2} \mathrm{O}_{3}(30.15-33.24 \mathrm{wt} \%), \mathrm{TiO}_{2}(0.05-2.33 \mathrm{wt} \%), \mathrm{FeO}$ (6.84-17.16 wt\%), $\mathrm{MgO}(0.89-7.00 \mathrm{wt} \%), \mathrm{Na}_{2} \mathrm{O}(1.41-$ $2.30 \mathrm{wt} \%), \mathrm{F}(0.0-0.69 \mathrm{wt} \%)$ along with $\mathrm{B}_{2} \mathrm{O}_{3}(10.58$ $11.56 \mathrm{wt} \%$ ) was measured (Table 2). Stoichiometric mineral formula was calculated using a computer program developed by Julie Seley and Jian Xiang ${ }^{42,43}$. The measured boron content was compared with that calculated (Figure 4) since the presence, albeit very limited, of boron at the tetrahedral $\mathrm{T}$ site has been reported in tourmaline from several localities. For example, tetrahedral boron $\left({ }^{\mathrm{IV}} \mathrm{B}\right)$ contents were reported with: (i) $\sim 0.25 \mathrm{apfu}$ from a schorl in a pegmatite near Stoffhütte, Koralpe, Styria, Austria ${ }^{44}$; (ii) $\sim 0.40$ apfu from a olenite in a pegmatite at Olenii Ridge, Russia ${ }^{29}$ and (iii) $\sim 0.17$ apfu from the metamorphic dravite in Syros, Greece ${ }^{45}$. In the studied samples, the measured boron content is slightly higher $(10.58-11.56 \mathrm{wt} \%)$ compared to that calculated (9.96-10.53 wt\%; Figure 5).

Tourmaline from the studied samples comes under the alkali group in general (Figure $6 a$ ) and belongs to the schorl-dravite solid solution series in particular. Brown tourmaline has been classified as schorl, whereas green tourmaline as the dravite variety (Figure $6 b$ ). This study highlights that boron measurement in tourmaline can be made using electron probe microanalysers equipped with PC3 crystal, and the resulting data can be used to better constrain its paragenesis.

1. Marschall, H. R., Korsakov, A. V., Luvizotto, G. L., Nasdala, L. and Ludwig, T., On the occurrence and boron isotopic composition of tourmaline in (ultra) high-pressure metamorphic rocks. J. Geol. Soc. London, 2009, 166, 811-823.

2. Lussier, A. J., Ball, N. A., Hawthorne, F. C., Henry, D. J., Shimi$\mathrm{zu}, \mathrm{R}$., Ogasawara, Y. and Ota, T., Maruyamaite, $\mathrm{K}\left(\mathrm{MgAl}_{2}\right)$ $\left(\mathrm{Al}_{5} \mathrm{Mg}\right) \mathrm{Si}_{6} \mathrm{O}_{18}\left(\mathrm{BO}_{3}\right)_{3}(\mathrm{OH})_{3} \mathrm{O}$, from the ultrahigh-pressure Kokchetav massif, northern Kazakhstan: description and crystal structure. Am. Mineral., 2016, 101, 355-361.

3. Dutrow, B. L. and Henry, D. J., Tourmaline: a geologic DVD. Elements, 2017, 7, 301-306.

4. Krynine, P. D., The tourmaline group in sediments. J. Geol., 1946, 54, 65-87.

5. Pettijohn, F. J., Potter, P. E. and Siever, R., Sand and Sandstones, Springer-Verlag, New York, USA, 1973.

6. Awasthi, N., Authigenic tourmaline and zircon in the Vindhyan formations of Sone Valley, Mizapur District, Uttar Pradesh, India. J. Sediment Petrol., 1961, 31, 482-484.

7. Ricketts, B. D., Authigenic tourmaline from the Middle Precambrian Belcheger group, Northwest Territories, Canada. Bull. Can. Pet. Geol., 1978, 26, 541-550.

8. Gautier, D. L., Preliminary report of authigenic, euhedral tourmaine crystals in a productive gas reservoir of the Tiger Ridge Field, north-central Montana. J. Sediment. Petrol., 1979, 49, 911 916.
9. Mader, D., Tourmaline authigenesis in carbonate-rock breccias from the upper Bunter of the northern Triev Bay; western Eifel. Der Aufschluss, 1980, 31, 249-256.

10. Henry, D. J., Novák, M., Hawthorne, F. C., Ertl, A., Dutrow, B. L., Uher, P. and Pezzotta, F., Nomenclature of the tourmalinesupergroup minerals. Am. Mineral., 2011, 96, 895-913.

11. Hawthorne, F. C. and Henry, D. J., Classification of the minerals of the tourmaline group. Eur. J. Mineral., 1999, 11, 201-215.

12. Donnay, G. and Barton Jr, R., Refinement of the crystal structure of elbaite and the mechanism of tourmaline solid solution. Tschermaks Mineral. Petrogr. Mit., 1972, 18, 273-286.

13. Rosenberg, P. E. and Foit Jr, F. F., Synthesis and characterization of alkali-free tourmaline. Am. Mineral., 1979, 64, 180-186.

14. Barton Jr, R., Refinement of the crystal structure of buergerite and absolute orientation of tourmalines. Acta Crystallogr., 1969, 25, $1524-1532$.

15. Tsang, T., Thorpe, A. N. and Donnay, G., Magnetic susceptibility and triangular exchange coupling in the tourmaline mineral group. J. Phys. Chem. Solids, 1971, 32, 1441-1448.

16. Gorelikova, N. V., Perfil'yev, Yu. D. and Bubeshkin, A. M., Mössbauer data on distribution of Fe ions in tourmaline. Int. Geol. Rev., 1978, 20, 982-990.

17. Foit Jr, F. F. and Rosenberg, P. E., The structure of vanadiumbearing tourmaline and its implications regarding tourmaline solid solutions. Am. Mineral., 1979, 64, 788-798.

18. Korovushkin, V. V., Kuzmin, V. L. and Belov, V. F., Mössbauer studies of structural features in tourmaline of various geneses. Phys. Chem. Miner., 1979, 4, 209-220.

19. Nuber, B. and Schmetzer, K., The lattice position of $\mathrm{Cr}^{3+}$ in tourmaline; structural refinement of a chromium-rich $\mathrm{Mg}-\mathrm{Al}$ tourmaline. Neues Jahrb. Mineral., Abh., 1979, 137, 184-197.

20. Burns, R. G., The blackness of schorl: $\mathrm{Fe}^{2+}-\mathrm{Fe}^{3+}$ electron delocalization in tourmalines. Trans. Am. Geophys. Union, 1982, 63, 1142 .

21. Frondel, C., Biedl, A. and Ito, J., New type of ferric iron tourmaline. Am. Mineral., 1966, 51, 1501-1505.

22. Hermon, E., Simkin, D. J., Donnay, G. and Muir, W. B., The distribution of $\mathrm{Fe}^{2+}$ and $\mathrm{Fe}^{3+}$ in iron-bearing tourmalines: a Mössbauer study. Tschermaks Mineral. Petrogr. Mitt., 1973, 19, 124-132.

23. Fortier, S. and Donnay, G., Schorl refinement showing composition dependence of the tourmaline structure. Can. Mineral., 1975, 13, 173-177.

24. Foit Jr, F. F. and Rosenberg, P. E., Coupled substitutions in the tourmaline group. Contrib. Mineral. Petrol., 1977, 62, 109-127.

25. Tsang, T. and Ghose, S., Nuclear magnetic resonance of ${ }^{1} \mathrm{H},{ }^{7} \mathrm{Li}$, ${ }^{11} \mathrm{~B},{ }^{23} \mathrm{Na}$ and ${ }^{27} \mathrm{Al}$ in tourmaline (elbaite). Am. Mineral., 1973, 58, 224-229.

26. Povondra, P., The crystal chemistry of tourmalines of the schorldravite series. Acta Univ. Carol-Geol., 1981, 3, 223-264.

27. Tagg, S. L., Cho, H., Dyar, M. D. and Grew, E. S., Tetrahedral boron in naturally occurring tourmaline. Am. Mineral., 1999, 84, 1451-1455.

28. Hughes, J. M., Ertl, A., Dyar, M. D., Grew, E. S., Shearer, C. K., Yates, M. G. and Guidotti, C. V., Tetrahedrally coordinated boron in a tourmaline: boron-rich olenite from Stoffhutte, Koralpe, Austria. Can. Mineral., 2000, 38, 861-868.

29. Schreyer, W., Hughes, J. M., Bernhardt, H. J., Kalt, A., Prowatke, S. and Ertl, A., Reexamination of olenite from the type locality: detection of boron in tetrahedral coordination. Eur. J. Mineral., 2002, 14, 935-942.

30. Ertl, A., Über die Etymologie und die Typlokalitäten des Minerals Schörl (about the etymology and the type localities of schorl). Mitt. Österr. Mineral. Ges., 2006, 152, 7-16.

31. Lussier, A. J., Aguiar, P. M., Michaelis, V. K., Kroeker, S. and Hawthorne, F. C., The occurrence of tetrahedrally coordinated Al and $\mathrm{B}$ in tourmaline: $\mathrm{An}{ }^{11} \mathrm{~B}$ and ${ }^{27} \mathrm{Al}$ MAS NMR study. $\mathrm{Am}$. Mineral., 2009, 94, 785-792. 
32. Nemec, D., Fluorine in tourmalines. Contrib. Mineral. Petrol., 1968, 20, 235-243.

33. Iyengar, K. Y. S., Fibrous tourmaline from the Mysore state. Curr. Sci., 1937, 10, 534-535.

34. Babu, S. K., Mineralogy of achroite (colourless tourmaline), from a pegmatite near Ajmer. Curr. Sci., 1969, 7, 154-156.

35. Bastin, G. F. and Heijligers, H. J. M., Quantitative electron probe microanalysis of ultralight elements (boron-oxygen). Scanning, 1990, 12, 225-236.

36. Ertl, A. et al., Toumaline of the elbaite-schorl series from the Himalaya Mine, Mesa Grande, California: a detailed investigation. Am. Mineral., 2010, 95, 24-40.

37. Henry, D. J., Viator, D. and Dutrow, B. L., Estimation of light element concentrations in tourmaline: how accurate can it be? In Programme with Abstracts of the 18th International Mineralogical Association, Edinburgh, Scotland, 2002, p. 209.

38. Mahadevan, T. M., Geology of Bihar and Jharkhand, Geological Society of India, Bengaluru, 2002, p. 563.

39. Acharyya, S. K., The nature of Mesoproterozoic central Indian tectonic zone with exhumed and reworked older granulites. Gondwana Res., 2003, 6/2, 197-214.

40. Sharma, R. S., Cratons and Fold Belts of India, Springer, Berlin, Germany, 2009, p. 304.

41. Singh, U. P., Venkatesh, N. S., Godhavari, K. S., Gopalkrishnan, R., Fareeduddin and Rao, M. S., Lamprophyre dykes in Chotanagpur gneissic complex, near Simdega, Gumla district, Jharkhand. J. Geol. Soc. India, 2004, 63, 655-658.

42. Tindle, A. G., Breaks, F. W. and Selway, J. B., Tourmaline in petalite-subtype granitic pegmatites: evidence of fractionation and contamination from the Pakeagama Lake and Separation Lake areas of northwestern Ontario, Canada. Can. Mineral., 2002, 40, 753-788.

43. Clark, C. M., Tourmaline: structural formula calculation. Can. Mineral., 2007, 45, 229-237.

44. Ertl, A. and Hughes, J. M., The crystal structure of an aluminumrich schorl overgrown by boron-rich olenite from Koralpe, Styria, Austria. Mineral. Petrol., 2002, 75, 69-78.

45. Marschall, H. R. and Ludwig, T., The low-boron contest: minimising surface contamination and analysing boron concentrations at the ng/g-level by secondary ion mass spectrometry. Mineral Petrol, 2004, 81, 265-278.

46. Naqvi, S. M. and Rogers, J. J. W., Precambrian Geology of India, Oxford University Press, New York, USA, 1987, p. 223.

47. Ray, J. N., Raurkela quadrangle map. Geological Survey of India, Ranchi, 1983.

ACKNOWLEDGEMENTS. We thank the Head, Department of Geology, Banaras Hindu University, Varanasi for support. N.V.C.R. thanks DST-SERB, New Delhi for a research project (IR/S4/ESF18/2011 dated 12.11.2013) to set up EPMA and SEM laboratories. D.K and A.S. thank CSIR, New Delhi for JRF(NET). We thank the two anonymous reviewers and the handling editor Somnath Dasgupta for their constructive comments which helped improve the manuscript.

Received 13 February 2019; revised accepted 6 June 2019

doi: $10.18520 / \mathrm{cs} / \mathrm{v} 117 / \mathrm{i} 5 / 858-865$
${ }^{137} \mathrm{Cs}$ - a potential environmental marker for assessing erosion-induced soil organic carbon loss in India

\author{
Debashis Mandal ${ }^{1}$, Nishita Giri ${ }^{1, *}$, \\ Pankaj Srivastava $^{1}$, Chinmay Shah ${ }^{2}$, \\ Ravi Bhushan ${ }^{2}$, Karunakara Naregundi ${ }^{3}$, \\ M. P. Mohan ${ }^{3}$ and Manoj Shrivastava ${ }^{4}$ \\ ${ }^{1}$ ICAR-Indian Institute of Soil and Water Conservation, \\ Dehradun 248 195, India \\ ${ }^{2}$ Physical Research Laboratory, Ahmedabad 380 009, India \\ ${ }^{3}$ Centre for Advanced Research in Environmental Radioactivity, \\ Mangalore University, Mangaluru 574 119, India \\ ${ }^{4}$ Indian Agricultural Research Institute, New Delhi 110 012, India
}

The use of Cesium-137 $\left({ }^{137} \mathrm{Cs}\right)$ as a potential environmental marker was examined for estimating soil erosion induced carbon losses on slopping agricultural land. Depth-wise incremental soil samples were taken from uneroded reference sites and four levels of cultivated slopping lands representing different erosion phase in Doon valley region of India. Comparing the ${ }^{137} \mathrm{Cs}$ inventories for eroded sites with the reference inventory, the erosion rates were computed. The estimated erosion rates were then compared with the actual measured values of erosion at each erosion phase. Since soil erosion preferentially removes the finer soil particles, these results were used to assess erosion induced loss of $\mathrm{OC}$. The result indicated that erosion in different phases relocate $137 \mathrm{~kg} \mathrm{C} \mathrm{ha}^{-1}$ in slightly eroded plots to $384 \mathrm{~kg} \mathrm{C} \mathrm{ha}^{-1}$ in severely eroded plots which in turn contributes to 27 to $77 \mathrm{~kg} \mathrm{C} \mathrm{ha}^{-1}$ the atmosphere as net source of $\mathrm{C}$ respectively.

Keywords: ${ }^{137} \mathrm{Cs}$ technology, soil erosion, soil erosion induced C-loss, soil conservation, slopping agricultural land.

SoIL erosion at slow rates is acceptable ${ }^{1}$. However, if it goes beyond the soil regeneration rate, then soil erosion becomes a destructive process ${ }^{2-4}$. Anthropogenic activities such as intensive cultivation and inappropriate soil management techniques have accelerated the process of soil erosion, therefore, worldwide it is now described as the principal form of degradation ${ }^{1,4}$. The demand for more agricultural productivity increased the pressure on land, leading to accelerated soil loss ${ }^{5-7}$.

Hill and mountain landscapes are most susceptible to erosion. Globally, nearly 1.1 billion ha ( $b$ ha) of land area is affected by water-induced erosion, of which about $0.75 \mathrm{~b}$ ha is in a severe state $^{1}$. Erosion process impacts the redistribution of soil material, including carbon colloids within a landscape ${ }^{8-12}$.

*For correspondence. (e-mail: nishi28nov@gmail.com) 